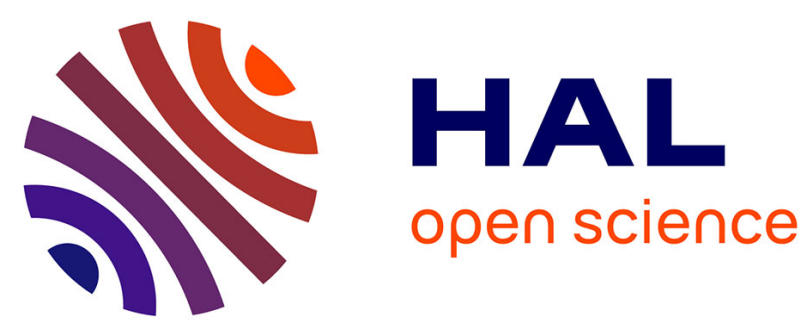

\title{
High oxygen pressures and recent developments in the field of high oxidation states
}

\author{
Gérard Demazeau, Michel Pouchard, B. Buffat, Paul Hagenmuller
}

\section{To cite this version:}

Gérard Demazeau, Michel Pouchard, B. Buffat, Paul Hagenmuller. High oxygen pressures and recent developments in the field of high oxidation states. Journal de Physique Colloques, 1984, 45 (C8), pp.C8-345-C8-351. 10.1051/jphyscol:1984862 . jpa-00224364

\section{HAL Id: jpa-00224364 https://hal.science/jpa-00224364}

Submitted on 1 Jan 1984

HAL is a multi-disciplinary open access archive for the deposit and dissemination of scientific research documents, whether they are published or not. The documents may come from teaching and research institutions in France or abroad, or from public or private research centers.
L'archive ouverte pluridisciplinaire HAL, est destinée au dépôt et à la diffusion de documents scientifiques de niveau recherche, publiés ou non, émanant des établissements d'enseignement et de recherche français ou étrangers, des laboratoires publics ou privés. 
HIGH OXYGEN PRESSURES AND RECENT DEVELOPMENTS IN THE FIELD OF HIGH OXIDATION STATES

\author{
G. Demazeau, M. Pouchard, B. Buffat and P. Hagenmuller \\ Laboratoire de Chimie du Sotide du CNRS, Université de Bordeaux I, \\ 351 Cours de la Libération, 33405 Talence Cedex, France
}

Résumé - Les hautes pressions d'oxygène sont très importantes dans la stabilisation de hauts degrés d'oxydation des éléments de transition. En utilisant des facteurs structuraux et de liaison chimique caractérisant l'environnement anionique des configurations électroniques inusuelles peuvent être obtenues. Le fer (V) en site $O H$ d'une part et le fer (IV) à spin fort ou le cobalt (III) de spin intermédiaire en site D4H ont été choisis pour illustrer ces diverses possibilités.

Abstract - High oxygen pressures are very suitable for the preparation of high oxidation states of transition elements. Using, in addition, appropriate structural and chemical bonding factors charactexizing the anionic surrounding unusual electronic configurations can be obtained. The stabilization of $\mathrm{Fe}(V)$ in an $\mathrm{OH}$ site and high spin $\mathrm{Fe}$ (IV) or intermediate spin Co (III) in a D4H symmetry have been selected to illustrate these possibilities.

\title{
During the last thirty years great progress
}

has been obtained in the stabilization of unusual oxidation states of transition elements using high oxygen pressures. Three main methods can be developped to generate high oxygen pressures:

- compressed oxygen gaz (1),

- oxydizing solutions such as diluted solutions of $\mathrm{NH}_{4} \mathrm{ClO}_{4}$ in an hydrothermal device (1),

- the thermal decomposition in solid state of unstable oxides such as $\mathrm{CrO}_{3}$ (2) or $\mathrm{KClO}_{3}$ (3) in a "belt" apparatus.

The oxidation state of an ion of a transition metal element is a formal number reflecting the average number of $d$ electrons involved in chemical bonding. Its stabilization closely depends on that of the corresponding electronic configuration, in particular on (i) structural factors (size and symmetry of the cationic site), (ii) nature of the cationic neighbours (covalence and influence of the competing bonds). 
Sugano's diagramms (1) and on the Krishnamurthy and Schaap's calculation of the energy of d orbitals in a $D_{4 h}$ symmetry (5). we have underlined the influence of the structural elongation of the $\mathrm{MO}_{6}$ octahedron on the stabilization of electronic configurations (6).

\section{I - STABILIZATION OF A VERY HIGH OXIDATION STATE: SIX- COORD INATED FE+V IN AN OXYGEN-LATTICE}

$\mathrm{Fe}+\mathrm{V}$ was unknown in octahedral coordination. Its isotropic electronic configuration $\left(t_{2 g}^{3}\right)$ fits very well with a pure octahedral site $\left(O_{h}\right.$ symmetry). To stabilize Fe+V it is necessary, in addition of the use of high oxygen pressures, to select structural and chemical bonding factors able to favorize : (i) an oh site, (ii) the covalency of the Fe-O bonds.

\section{With this selected stoichiometry, $\mathrm{La}_{2} \mathrm{LiFeO}_{6}$,} has been prepared under high oxygen pressure $(70 \mathrm{kbar})$. Chemical and physical characterizations confirm the stabilization - for the first time - of pure six coordinated FetV in an oxide (Table I) (7).

\section{2 - STABILIZATION OF AN UNUSUAL ELECTRONIC CONFIGURATION: HIGH SPIN FE+IV IN AN OCTAHEDRAI SITE}

Owing to the evaluated $\mathrm{Dq} / \mathrm{B}$ value for six-coordinated $\mathrm{Fe}+\mathrm{IV}$ in an oxygen lattice (Dq/B $\simeq 4$ ), in the Fe+IV oxides so far prepared - mostly with the perovskite structure $\mathrm{Fe}+\mathrm{IV}$ seems to have a low spin configuration $\left(\mathrm{SrFeO}_{3}\right)(8-11)$ related to some electronic delocalization $\left(\mathrm{CaFeO}_{3}\right)(1-12-15)$.

Using the previous model, a strong elongation of the $\mathrm{FeO}_{6}$ octahedron seems to be appropriate to stabilize the high spin state $\left(t_{2 g}^{3} e_{g}^{l}\right)$ (Fig. 1 ).

Choosing a $\mathrm{K}_{2} \mathrm{NiF}_{4}$ layer structure stacking of rocksalt and perovskite layer (Fig.2) and four weak $\mathrm{Li}-\mathrm{O}$ bonds as competing bonds in the perovskite layer, such a distortion can be induced. The corresponding oxides 
$\mathrm{A}_{0.5^{\mathrm{La}} 1.5^{\mathrm{Li}} 0.5^{\mathrm{Fe}}(\mathrm{IV})} 0.5^{\mathrm{O}_{4}} \quad(\mathrm{~A}=\mathrm{Ca}, \mathrm{Sr}, \mathrm{Ba})$ have been selected and prepared under oxygen pressure.

Chemical and physical characterizations are in agreement with Fe+IV with four unpaired electrons (high spin state)

\begin{tabular}{|c|c|c|c|c|c|}
\hline & $\begin{array}{c}\text { oxidation } \\
\text { state }\end{array}$ & $\begin{array}{l}\text { molar aurie } \\
\text { constant }\end{array}$ & $\begin{array}{c}\text { isomer shift } \\
300 \mathrm{k} \\
\text { (MBssbauer) } \\
\mathrm{mm} . \mathrm{s}^{-1}\end{array}$ & $\left|\begin{array}{c}\text { quadrupole } \\
\text { splitting } \\
\mathrm{mm} . \mathrm{s}^{-1}\end{array}\right|$ & $\begin{array}{l}\text { g value } \\
\text { (RPE) }\end{array}$ \\
\hline $\begin{array}{l}\text { observed } \\
\text { values }\end{array}$ & 5,02 & 1,93 & $-0,41$ & 0 & 2,0135 \\
\hline $\begin{array}{c}\text { theoretical } \\
\text { values }\end{array}$ & 5 & 1,875 & $\begin{array}{l}\text { unknown, but } \\
\text { probably } \\
\text { very negati- } \\
\text { ve value }\end{array}$ & 0 & 2,0131 \\
\hline
\end{tabular}

Table I

\begin{tabular}{|c|c|c|c|c|}
\hline & $\begin{array}{c}\text { oxidation } \\
\text { state }\end{array}$ & $\begin{array}{c}\text { Curie } \\
\text { Constant }\end{array}$ & $\begin{array}{c}\text { isomer shift } \\
300 \mathrm{~K} \\
\text { (Mbssbauer) } \\
\text { mm.s }\end{array}$ & $\begin{array}{c}\text { quadrupale } \\
\text { splitting }\end{array}$ \\
\hline $\begin{array}{c}\text { observed } \\
\text { values }\end{array}$ & 3.97 & 3.06 & -0.19 & 1,2 \\
\hline $\begin{array}{l}\text { low spin } \\
\text { Fe (TV) }\end{array}$ & 4 & 1 & (in SrFe0 3$)$ & small \\
\hline $\begin{array}{l}\text { Figh spin } \\
\text { Fe (IV) }\end{array}$ & 4 & 3 & unknown & $\begin{array}{l}\text { unknown but } \\
\text { probably im- } \\
\text { portant owing } \\
\text { to the Jahn } \\
\text { Teller distor- } \\
\text { tion }\end{array}$ \\
\hline
\end{tabular}




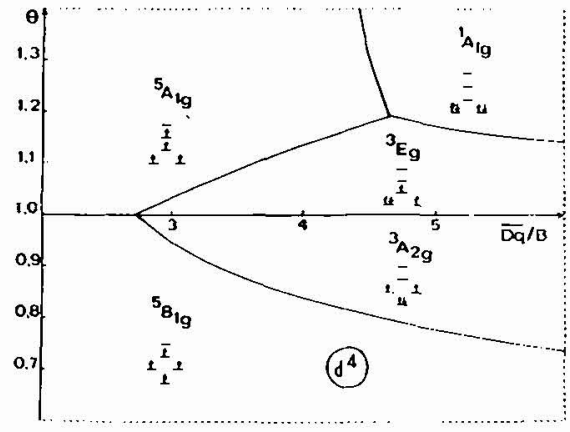

Fig.1 - Ground state regions for a $\mathrm{d}^{4}$ configuration

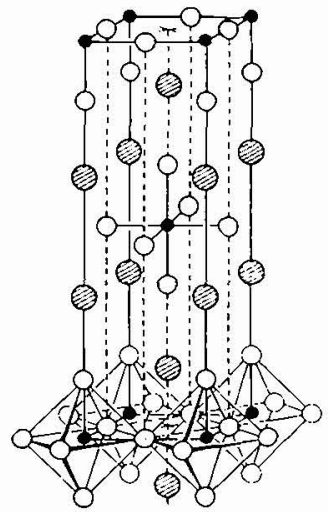

K OF $\quad$ N

Fig. 2 - The $\mathrm{K}_{2} \mathrm{NiF}_{4}$ structure

\section{3 - STABILIZATION OF AN INTERMEDIATE ELECTRONIC CONFIGURATION DURING A SPIN TRANSITION: "MEDIUM SPIN" CO+III}

In an oxygen lattice and in an octahedral site a low spin $\left({ }^{1} A_{1 g}\right)$ - high spin $\left({ }^{5} T_{2 g}\right)$ transition occurs with increasing temperature for Co+III (Dq/B value being close to the critical Dq/B value). Such a phenomenon has been observed in the $\mathrm{InCOO}_{3}$ perovskites ( $\mathrm{Ln}=$ rare-earth) prepared under oxygen pressure (15) (Fig.3).

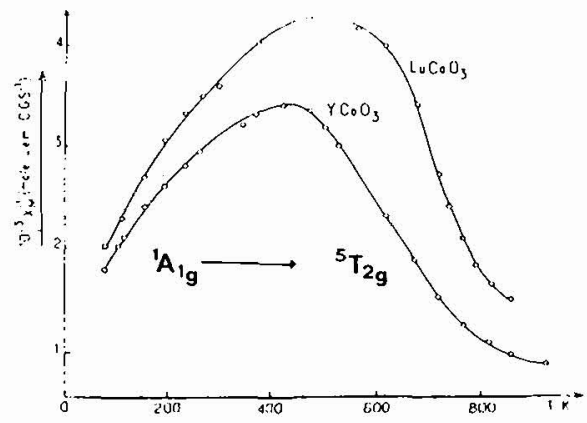

Fig.3 - Variation with temperature of the reciprocal molar magnetic susceotibility for $\mathrm{YCOO}_{3}$ and $\mathrm{IuCOO}_{3}$ phases 
Using the simple model described earlier (Fig.4), an intermediate electronic configuration $\left(a_{y z}^{2} d^{2} z x_{x y}^{d} d^{l}{ }^{2}{ }_{x}^{0}{ }^{2}-y^{2}\right.$ $S=1)$ can be predicted for CotIII in an elongated octahedron $(\theta>1,15)$.

Such an unusual configuration has been detected as intermediate state during the ${ }^{1} \mathrm{~A}_{1 \mathrm{~g}}+{ }^{5} \mathrm{E}_{\mathrm{g}}\left({ }^{5} \mathrm{~T}_{2 \mathrm{~g}}\right)$ transition in the two oxides prepared under oxygen pressure: $\mathrm{La}_{2} \mathrm{Li}_{0.5} \mathrm{Co}$ (III) $0.5^{\mathrm{O}} 4$ and $\mathrm{La}_{2}{ }^{\mathrm{Li}} 0.5^{\mathrm{Cu} \text { (III) }} 0.45^{\mathrm{Co} \text { (III) }} 0.05_{4} \mathrm{O}_{4}$ (16) (Fig.5) (the increasing elongation of the $\mathrm{CoO}_{6}$ octahedron favorizing the stability of this configuration with the ${ }^{3}{ }^{B_{2}}$ term).

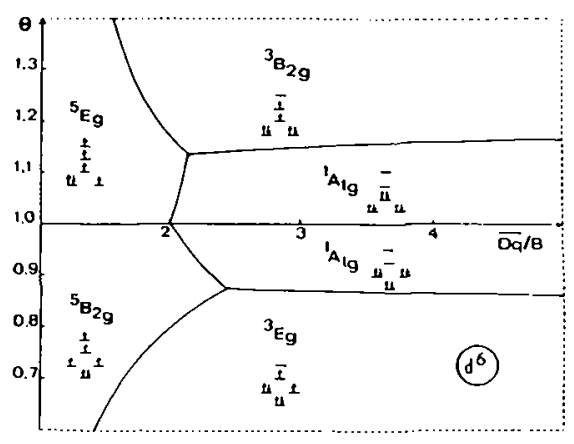

Fig. 4 - Ground state regions for a

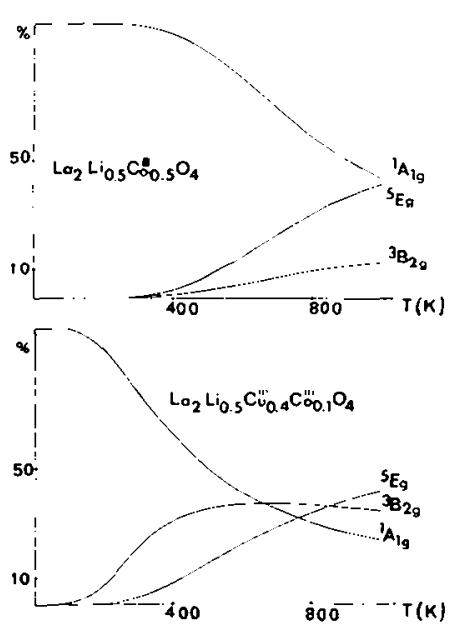
$d^{6}$ configuration

Fig. 5 - Comparison of the populations for the different terms in $\mathrm{La}_{2} \mathrm{Li}_{0.5} \mathrm{Co}_{0.5} \mathrm{O}_{4}$ and $\mathrm{La}_{2} \mathrm{Li}_{0.5} \mathrm{Cu}_{0.40^{\mathrm{CO}}} \mathrm{C}_{0.10^{\circ}}$

\section{CONCLUSIONS}

High oxygen pressures can help the synthesis of oxides containing unusual oxidation states or electronic configurations of transition elements. Such materials lead to a better understanding of the chemical bond. 


\section{REFERENCES}

(I) G. Demazeau, M. Pouchard and P. HAGENMULLER, High pressure in Research and Industry, vol.2 1982, 8 th AIRAPT, 19 th EMPRG Conf. (Ed. CM. Backman, T. Hohannisson, I. Tegner).

(2) E. Kanamaru, M. Miyamoto, Y. Mimura, M. Koizumi, M. Shimada, S. Kume and S. Shin, Mat. Res. BuIl. 5, 257, 1970.

(3) G. Demazeau, Thà se doctorat ès sciences Bordeaux 1973.

(4) Y. Tanabe and S. Sugaro,

J. Phys. Soc. Japan, 9, 753, 2954.

(5) R. Kristhnamurthg and W.B. Schaap

J. Chem. Educ., 46, 799, 1969.

(6) B. Buffat, G. Demazeau, M. Pouchard and P. Hagenmuller Proc. Indian Acad. Sci. (Chem. Sci.) 93 (3), 313, 1984.

(7) G. Demazeau, B. Buffat, F. Menil, L. Fournès, M. Pouchard, J.M. Dance, R. Fabritchnyiand P. Hagenmulier, Mat. Res. Bull., 16, 1465, 1981.

(8) M. Watanabe,

J. Phys. Soc. Japan 12 (5), 515, 1957

(9) P.K. Gallagher, J.B. MacChesney and D.N.E. Buchanan, J. Chem. Phys. 41 (8), 2429, 1964.

(10) J.M. MacChesney, R.C. Sherwood and J.F. Potter, J. Chem. Phys., 43 (6) 1907, 1965.

(11) T. Takeda, Y. Yamaguchi and W. Watanabe, J. Phys. Soc. Japan, 33 (4), 967, 1972.

(12) Y. Takeda, S. Naka, M. Nakano, T. Shinjo, T. Takada and M. Shimada, Mat. Res. BuIl. 13, 61, 1978. 
(13) M. Takano, N. Nakanishi, Y. Takeda, S. Naka and T. Takada, Mat. Res. Bull. 12, 923, 1977.

(14) G. Demazeau, N. Chevreau, I. Fournès, J.I. Soubeyroux, Y. Takeda, M. Thomas and M. Pouchard,

Rev. Chim. Minérale, 20, 155, 1983.

(15) G. Demazeau, M. Pouchard and P. Hagenmiler,

J. Sol. State Chem., 8, 109, 1973.

(16) B. Buffat, G. Demazeau, M. Pouchard and P. Hagenmullex, Mat. Res. Bull., 18, 1153, 1983. 